\title{
Township Tourism: The politics and socio-economic dynamics of tourism in the South African township: Umlazi, Durban
}

\author{
Nsizwazikhona Simon Chili \\ Durban University of Technology, South Africa \\ nsizwazikhonac@dut.ac.za
}

\begin{abstract}
The paper analyses how tourism development at Umlazi which is one of the second biggest Townships in the Southern hemisphere has been hampered by politics and socio economic dynamics that stifle the empowerment of both tourism entrepreneurs and local communities respectively. The impacts of tourism have been given much attention by scholars to examine the perceptions and attitudes of local residents towards Township tourism in South Africa. However, there is little research that focuses on how much political and economic dynamics of the past and present dispensations have adversely impacted on the tourism economic development of small emerging entrepreneurs and local residents of the Townships. This study attempts to make a little contribution to South African Township tourism by examining political and economic dimensions that hinder small businesses and local residents of uMlazi to thrive and get empowered through tourism. Township tourism in South Africa has slightly improved and grown in popularity since 1994 and is considered by the government and other social agents to be an appropriate opportunity for small businesses and the stimulation of local economic development. However, the paper argues that tourism fails to act as a panacea of economic development in the township of Umlazi, since there is lack of business opportunities, intervention and support of local government, private sector and racial groups that are endowed with more than enough financial resources. Data were collected by means of interviews that allowed the interviewer to pose some open-ended questions so that the interviewee could express his or her own opinion freely for the extraction of more information. Based on 30 respondents surveyed, the findings show that there are numerous obstacles that are directly linked to political and economic dynamics. These obstacles include lack of political intervention and financial support for tourism entrepreneurs and local residents of UMlazi Township. On the whole respondents viewed Township tourism negatively. They were generally of the idea that township tourism can only be of benefit to residents once it is often visited by racial groups who are better off financially after their fears about safety and security have been allayed.
\end{abstract}

Keywords: Townships; financial support; tourism; economic development; small businesses

\section{Introduction}

Township tourism in South Africa has grown in popularity since 1994 and is considered by some especially in the government circles to be an appropriate mechanism for stimulating job creation and local economic development (Bonn et al, 2007). Yet several problematic and political issues related to the implementation of tourism policies for tourism development to create jobs as claimed are evident in the township tourism literature. Struggles over tourism development in most of the African states or throughout much of the temporary sub-Sahara Africa, are to a large degree simply windows into wider contests over market access, economic and political empowerment, and citizenship (Diamonds \& Plattner, 2010). In Africa, the political character of the post- colonial state shapes these struggles in fundamental ways. Contextualising efforts to link tourism development and poverty reduction within these wider political -economic systems is central to understanding the outcomes observed, and to develop appropriate strategies that can effectively address these challenges. This paper focuses on political and socio- economic dynamics that adversely affect the prosperity of small tourism entrepreneurs and the local residents of Umlazi Township in the province of KwaZulu-Natal in South Africa who should in essence be beneficiaries of tourism development. Umlazi township was politically popularised and became a centre of attraction in the early 80's when a political civil lawyer was brutally slain by the agents of an oppressive government, whose wife was also assassinated in the driveway of her home in front of her children by four men (security police) shortly after speaking at the funeral of four freedom fighters known as Craddock four. 
Alden (2011) argues that tourism development itself is often part and parcel of elite patronage or accumulative interests; political elites and their allies are often significant investors or shareholders in tourism properties and development. This is partly because elites have privileged access to and control over land and other state-held assets. The existing political-economic order in most African countries creates substantial barriers to ordinary citizens' entry into tourism markets (Nelson, 2011).Tourism is increasingly and incessantly being recognised for its economic potential and its contribution to poverty alleviation (UNWTO, 2006; Spenceley, 2008). Bonn et al (2007) however, points out that tourism benefits often do not filter down to poor communities. It is thus critically important to investigate obscured political socioeconomic dynamics that make it highly impossible for township residents to benefit socially and economically from tourism as an industry even though it is regarded as a panacea for poverty alleviation (Ashworth, 2004). Honey (2008) argues that while Africa 's tourism industry itself thrives based on the blessing of the continent's natural and cultural assets, and the tourism role in development policies becomes increasingly mainstreamed, most countries including South Africa are also establishing themselves as an emblematic cases of contradictions and tensions that constrain sustainable tourism development in Africa. While national policy makers extol the potential of tourism, local communities living alongside leading tourism sites proclaim that tourism is a curse to us (Rogers, 2004).

Ashworth (2004) contends that the development of township tourism is merely an exploitation of heritage and suffering of others for pleasure and entertainment of visitors. According to Pirie (2007) tourists are often taken to township areas on superficial journeys and in most cases there is very little or limited interaction between them and the local residents. There is a constant struggle between market viability and authentic representations of local cultures and tourists are regularly taken on pseudo-trips that do not reflect past or present realities (Ramchander, 2007). Another critical question with regard to township tourism is whether real opportunities for job creation and economic empowerment in general are accessible to local residents. There is no tangible and practical proof that the socio economic conditions of township residents are changed by tourism (Nemasetoni \& Rogerson, 2007). Nemasetoni\& Rogerson (2007) argue that because of constrained access to markets, limited funds for marketing and lack of support from established enterprises and political municipal authorities, the majority of black tour operators become marginalised in a situation of large firm dominance of the tourism operating industry as a whole. It is on the basis of the above aforementioned assertions that this paper argues that tourism even in the biggest townships of South Africa such as Soweto and Umlazi is not necessarily a viable or responsible developmental option, since political transformation still fails to create opportunities for pro-poor to benefit from township tourism as it is arguable non-existent. Although the political and economic liberalization that has taken place since 1994 in South Africa has created much greater flows of investment and revived economic activity in many sectors, but tourism has not developed significantly to empower Township emerging entrepreneurs and Local residents thereof.

\section{Literature review}

According to Chachage \& Mbunda (2009) there are a range of fundamental implications for tourism development patterns and process that emanate from political economic dynamics in the African states. Firstly, tourism development itself is often a part and parcel of elite patronage or accumulative interests; political elites and their allies are often significant investors or shareholders in tourism properties and developments. This is partly because elites have privileged access to and control over land and other stateheld assets (Renton, 2009). Alden (2011) argues that high level of corruption, coupled with centralized discretionary authority, result in the state serving the private interest- for dispensing patronage and personal enrichment- of those in power. Until 1994 heritage tourism in South Africa essentially was synonymous with 'white heritage' and reflected exclusively the needs and interests of the countries' white minority (Gasper et al., 2005). Visser \& Rogers, (2004) suggest that the emergence of 'township tourism' is largely a phenomenon of the post-apartheid period that has stimulated curiosity and popularity for townships to attract more tourists to the sites of significance to anti-apartheid movement as well as improving tourists' understanding of poverty issues of historically oppressed communities. Indeed, township tourism has been termed a South African variant of justice tourism because of its features that are mostly symbolic of the past apartheid system (Scheyvens, 2002). Although the South African Department of Trade and Industry (DTI) has identified tourism as a socio-economic developmental strategy and one of the priority sectors that warrants promotion 
for Townships, studies suggest that there has been little empirical evidence to prove that attention is devoted to issues surrounding the development of tourism Small Medium Enterprises and the empowerment of local residents (Visser and Rogers, 2004). In variably, the existing literature is dominated by studies of the accommodation sub-sector and specifically of white owned bed and breakfast establishments or small guesthouses (Visser and Kotze, 2006; Rogerson \& Visser, 2007).

Moreover, throughout the apartheid period, high levels of political violence made the black townships 'no go zones for white international and white domestic tourists (Van Staden \& Marais, 2005).In fact even today 20 years later when apartheid was substituted by a democratic government in South Africa, whites in the country hardly set foot to townships, to them townships are still no go zones. In consequence, there is little or no evidence proving that the poorest of the poor benefits significantly from tourism generally or more specifically from township tourism (Nemasetoni and Rogers 2007; Ramchander 2007; Rogerson 2004; Saayman et al. 2012).Local entrepreneurs, who initially organised township tourism, face various challenges such as fierce competition from established, predominantly white-owned tour operators who have since entered the market, limited skills and access to finance and a weak product base (Rogerson 2004, 2008, 2013; Rolfes 2010). Other studies suggest that township tourism needs to be developed more responsibly to ensure economic opportunities for small emerging entrepreneurs and local communities (Booyens, 2010; Briedenhann and Ramchander, 2006; Ramchander, 2007; Rogerson, 2013). Briedenhann and Ranchander (2006) also suggest that it is the responsibility of the tourism industry and the government especially at local level to ensure that local communities share the benefits of township tourism without being exploited in the process.

Jurgens et al. (2013) argue that townships have emerged in recent years as priority areas for urban restructuring and economic development. According to Scheyvens (2002) there is a striking absence of formal economic activity in the townships in contrast with its sizeable resident population. Ngxiza (2012) argues that with reference to the townships of South Africa, there is a lack of opportunities, absence of robust economic base as well as chronic skills shortage. Jurgens et al. (2013) argue that townships leapfrogged immediately to a post-industrial economy characterised by leisure facilities such as shopping malls, accommodation establishments and museums. Townships are therefore repositioning themselves on the pleasure periphery and are emerging as niche markets for leisure and tourism (Jurgens et al. 2013). Jurgens et al. (2013) propose that critical questions need to be asked about the emerging market for tourism and leisure in townships and about the sustainability of such activities. Notwithstanding this, there is a desperate need for viable economic development in townships of South Africa to stimulate local economic growth and alleviate poverty (Jurgen et al. 2013). According to Booyens (2010); Rolfes et al. (2009) South Africa visitors have very limited interaction with Township residents.

GTA (2001) asserts that township tourism offers visitors visual evidence of the deprivation wrought by the apartheid regime. Poverty is ubiquitous, a factor that makes the lives and indomitable spirit of township dwellers even more admirable. Squatter camps, or informal settlements, are home to many of the escalating number of unemployed who use corrugated iron sheets, or any other available material to build shelters. Lacking basic amenities such as running water and electricity which manifested itself to load shedding during the conduction of the study and shelters that are hot in summer and cold in winter make for hazardous living. Despite their poverty, the shack dwellers have built a strong sense of community. Other manifestations of apartheid include the original dwellings, sardonically known as 'matchbox houses' constructed to accommodate Blacks who were forcefully removed from Glebelands and Clairwood. Initially Umlazi was an outskirt which was unilaterally turned by an oppressive regime into a township and the dwellers were the first occupants of newly build houses. Unfortunately the democratic government which was incepted in 1994 has continuously failed to manifest itself to socio-economic transformation for township communities. Tourism has always been a missed opportunity. Sakolnakorn (2013) suggests that the policy guidelines for tourism development in poor communities should necessitate the government agencies. The study concurs with Sakolnakorn and further suggests that the government agencies should be involved in tourism policy focus on several aspects that can assist in empowering township communities. Page (2003) argues that the local governments need to support all tourism activities and increase of the number of tourists. Watanasawas, (2011) also regards empowerment and sustainability as one of the necessities of daily life for both communities and tourists. That is why the study considers security and access to township tourism as one of the aspects that the local government officials involved in tourism should consider in order to empower 
Township communities. The study also suggests that for the sustainability of tourism development in townships, the government at all levels from National to Local, should consider the concerns of all tourism role-players especially the small business entrepreneurs and local communities.

\section{Methodology}

The main objective of the study was to determine political and socio economic factors behind the inability of tourism to be able to transform Umlazi Township to become an engine for economic development for emerging small entrepreneurs and local residents. The research paper was influenced by studies of Rogerson (2013) and Rolfes (2010) which concluded that tourism entrepreneurs in townships face challenges such as fierce competition from other well established white competitors who were previously favoured by the past regime. The paper further argues that the inability of townships to be able to develop and play an integral role in tourism is due to a political history of South Africa that excluded black entrepreneurs to participate in the economic mainstream. This qualitative study has precisely focussed on political dynamics that retard tourism from playing a mammoth task of achieving socio economic development for emerging entrepreneurs and local residents at uMlazi Township, and the following themes drawn from research questions were generated as core constructs for unstructured interviews comprising of open-ended questions which at some stage could be posed by the researcher to allow interviewees to participate freely.

- The extent that the political past and present affected adversely tourism economic development in the uMlazi Township,

- Whether the democratic municipal authorities support and provide security to small business entrepreneurs involved in tourism in the Township.

- Whether local municipal authorities do capacitate and give Township communities a hands-on training in order for them to benefit from tourism activities.

- Whether the function and existence of Community Tourism Organisations (CTO,s) assist their businesses and local residents

- Whether small business entrepreneurs do access funding to run their businesses in order to expedite tourism economic development through job creation for residents in the Township.

Research Instrument: An unstructured interviews that allowed the interviewer to pose some open-ended questions when need be for respondents to express their opinions freely were developed. Data collection was solicited and executed from 50 respondents. The representation of respondents included 4 emerging tourism entrepreneurs who participated freely and robustly at uMlazi Township, two Community Tourism Organisations (CTO,s) comprising of 10 active members and5EThekwini Municipality Tourism representatives2 representatives from Tourism KwaZulu-Natal and 30community members. The first 10 questions related to the extent on which tourism entrepreneurs and local communities were directly affected by apartheid and the present democratic government. Question 11 to 19 referred to the perceptions of entrepreneurs regarding the role of eThekwini municipality in the provision of security for tourists visiting their businesses. 20 to 30 questions were about the existence, function and the role of Community Tourism Organisation to ensure that the local communities become beneficiaries of tourism.Questions31 to 39were referring to the local community in terms of the role of the municipality authorities(Tourism KwaZulu-Natal) to capacitate and empower them. From question 40 to 50small tourism entrepreneurs were required to elaborate on the role of the municipality as an organ of government, financial institutions such as banks and private sector in assisting them to solicit funding in order to kick start or take their businesses to another level.

Data Collection: The Data were collected in five days as it depended on the availability of respondents. The process of interaction between the researcher and respondents took place in July 2014 and lasted for five days as already mentioned above. The interviewing interactive process involved four emerging tourism entrepreneurs whose businesses were confined and restricted to two Bed and breakfast and two classy and famous multi-purpose attractions known as Kwa-Max Life style and Eyadini, thirty community members, Community Tourism Organisations, Ethekwini Municipality Tourism representatives and Tourism KwaZuluNatal as broadly aforementioned. The duration of interviewing for each respondent lasted for more or less than 30 minutes. To execute the above mentioned tasks on the concerns driving the study, open ended and 
un-structured questions were developed and used as a tool for interviewing the managers of a few tourismrelated enterprises in uMlazi. Due to very few and limited tourism-related enterprises at Umlazi, the study only focussed on two bed and breakfast owners and two main and famous tourist attractions called Kwa Max Lifestyle and Eyadini. The latter attractions render multi-functional services such as that of a restaurant, a bar, braai meat facilities and huge space used by various kwaito and African hip hop National artists when entertaining young and middle age extroverts and music fanatics.

Data Analysis: Raw data previously transcribed from respondents during interviews were categorised as themes that were inextricably linked to research questions. Themes of concern were formulated in order to examine adverse effects of politics on small businesses, barriers of local communities to achieve tourism economic development in the township, municipality and financial support for small tourism entrepreneurs, opportunities, support, and provision of security by eThekwini Municipality, the assistance of Community Tourism Organisation to small businesses and local residents and finally barriers to access funds by emerging small business entrepreneurs to fast track tourism development and job creation in the Township. Capturing of data was achieved through transcribing and tape recording. This was precisely done for accuracy sake to avoid spicing what came from respondents and also to ensure making logical inferences from data collected. Reliability and validity was achieved through ensuring that all respondents were asked questions in accordance to their language of preferences to prevent unnecessary misinterpretations and misunderstanding.

\section{Discussion of results}

Open ended questions used for unstructured interviews were designed for all targeted groups of stakeholders as aforementioned: emerging tourism entrepreneurs, community tourism organisations Ethekwini municipality tourism representatives and community members. The overall attitude of stakeholders towards the role of politics to ensure economic development of the residents in the Township of tourism is negative. Tourism is not seen as the main branch for the empowerment of residents and small businesses in the Township of Umlazi. The results show that the support of the municipality as the segment of the National government to transform the residents of uMlazi through tourism is week among the stakeholders. Furthermore, stakeholders themselves have developed a negative attitude towards everything that has something to do with tourists and the government. Local residents strongly perceive the inability of tourism to change their plights as an attribution of government policies that fail to translate to reality.

Past and present political effects on tourism economic development: All the respondents suggested that the apartheid era in South Africa with its repressive laws, constitutionalised racism and high levels of political violence made the black township no go zones for financial well- off races. So tourism became a missed opportunity for township communities. Eruption of sporadic political violence in the South African townships before 1994 threatened the safety and security of tourists which then prevented tourism activities from taking place in uMlazi. However, during the democratic political transition, relatively some townships gradually became accessible to tourists and opportunities have opened for black South African communities with the exception of Umlazi. Findings suggest that there are two main tourism attractions at V section in Umlazi that are very close to each other. The present democratic government is not significantly offering township residents opportunities for economic development. The study reveals that there are very few residents who are benefiting from tourism in Umlazi Township. Residents confess that the government is unable to help them so there is absolutely no tourism economic development at uMlazi. The Ethekwini municipality is unable to assist different enterprises as well. A range of obstacles in terms of tourism offering in uMlazi were revealed. For instance, the absence of awareness campaigns to capacitate and train residents to survive through tourism was highlighted. Small business entrepreneurs echoed the same sentiments. For instance, one entrepreneur whose business is doing very well blames Ethekwini local municipality for failing to make uMlazi tourism destination. His opinion is that the municipality is unable to deliver key infrastructure including security and tourism business skills to Township communities. The respondent claims that the provision of security for tourists and local visitors has become his responsibility since his attempts to ask metro police to assist during hectic weekends have proven to be fruitless. He echoed that the local municipality even fails to provide signage for their businesses and applying to obtain an Operating Licence as compliance takes long for blacks. The compliance costs and membership costs are quite 
burdensome and not easy to obtain so some aspirant small entrepreneurs operate without registered under Southern African Tourism Services Association (SATSA).

The Southern African Tourism Services Association (SATSA) is the definitive association for members of the inbound tourism industry. It is a member-driven association that spans all sectors including accommodation, transport, tour and adventure operators, publicity associations and other tourism services. There is however, little evidence that the residents benefit significantly from township tourism. There is neither capacitation for communities to be enlightened about the nitty gritty of tourism nor assistance rendered by tourism community organisations if ever they do exist. Two mega businesses that serve as a trump card for Umlazi Township as tourists' destination cannot provide significant jobs for the entire communities of Umlazi. Some residents take an advantage of these businesses and work as car guards who look after visitors' cars who always patronise these two major entertaining tourist spots. In reality there is no tourism that benefits most of umlazi residents. There is absolutely no development in terms of access to entrepreneurship and employment opportunities, small business support, participation in decision making and local tourism product ownership.

Municipality and financial support for small tourism entrepreneurs: There is no direct access to funding through the assistance of the national government support programmes for small business, the entrepreneurs' lack of collateral or credit track record emerged as a stumbling block for business development. According to a successful business interviewee "because of the absence of collateral, it was difficult if not possible to get a loan from the bank and the inability of the government to intervene and force banks to assist township entrepreneurs is worrisome in a new democratic dispensation. I am so proud that my business is so successful although it was never funded".

Accessing funds to expand small tourism businesses in uMlazi Township: The survey disclosed that the business of the emerging entrepreneurs of uMlazi township is confronted by an array of challenges in terms of its further expansion. The interviewees revealed that the two core problems of uMlazi entrepreneurs concern access to sources of finances and access to markets and marketing support. It's only two massive and classic attraction called kwa-Max Lifestyle and Eyadini that show no sign of desperation in terms of finances and markets. Owners of the aforementioned successful businesses boast that the growth of their businesses is inexorably. The general concerns and frustration of the small business entrepreneurs in accessing finances are captured in interview responses that follow:

"It is not easy to access funds. My business plan was turned down and the reason stated was on the basis of it being sub-standard".

"Trying to apply for funding from banks was also a waste of time as one has to respond to many questions that were related to the possession of assets and investments to cede with in order to be considered".

\section{Conclusion}

Studies conducted on township tourism suggest that it is significantly important for the industry to create economic opportunities for residents in townships. Tourism is construed as a panacea and sector that plays an integral role in the contribution to shared growth in urban areas. Unfortunately in this paper findings revealed a contrast of what tourism is claimed to be doing in other townships of South Africa such Soweto and Cape Town as suggested by research of (Nemasetoni and Rogerson 2007). The above mentioned townships are portrayed as markets for both National and International tourists there by creating good economic opportunities for local residents. In contrast this study exposes that political and economic challenges stifle and retard the development of tourism in the Umlazi Township and there is absolutely no evidence that the residents get empowered through political interventions and financial institutions to be beneficiaries of tourism. There are only two viable tourism related businesses in the Township and strangely they are at close proximity and self-funded. In the whole, Umlazi Township is not a tourist destination as it is insignificantly lacking tourist attractions to be used as draw cards for other well off races that still regard Townships as unsafe places for entertainment. In fact safety and security is one of the main factors that make the Township unpopular to tourists. The majority of uMlazi residents are not getting any opportunities that are derived from tourism economic development and there are also contradicting and negative opinions 
about kwa-Max Life style and Eyadini as major tourist attractions which are located within 5000 meters apart. The most residents around these two attractions regard them as a nightmare and an infringement to their rights. They cite uncontrollable parking and hooliganism in their area as manifestation of the two businesses as they are always packed into full capacity during weekends. On the other hand the demand for the two main tourist attractions is an indication of the short-supply of tourist attractions in Umlazi which is exacerbated by the inability of the emerging entrepreneurs to source finances through the intervention and support of the government, Ethekwini municipality and Tourism KwaZulu-Natal. This explicitly means if there is no proliferation of tourism businesses in the township there will also be no opportunities created for residents. Furthermore this paper indicates that there is a huge perceived gap in the market for creative

tourism development in the Township of Umlazi that is situated in the south west of Durban in the coast of KwaZulu-Natal.

The present paradox attributed to challenges concerning efforts to direct tourism towards poverty reduction in South African townships is derived from the fact that socially, economically and politically beneficial forms of tourism depend largely on the ability of the municipalities and flexible laws to allow entrepreneurs and local residents to source finance to start small tourism businesses. Spenceley (2008) argues that sustainability tourism is thus largely depending on certain configurations of power, resource rights and governing authority that empower local groups of people, i.e. "the poor". The foremost implication of the political-economic state of affairs with respect to developing forms of tourism that significantly empower township residents is that efforts to link tourism with socio-economic development in Townships must take account of economic and political dynamics otherwise tourism will always be a missed opportunity for township residents. This paper also argues that local and national political dynamics over tourism economic developmental trajectory that impact, in many cases on poor communities are relatively ignored as a subject of tourism-related scholarship. Therefore the inferences deduced from the study are that very little is known about the critical political-economic dimensions on tourism development regarding the townships of South Africa, or in most of the African countries which are so influential in shaping both policy development and tourism outcomes on the ground. In spite of South Africa being known for having good policies, implementation has explicitly become a challenge. So the study asserts that the achievement of economic development to change the socio economic status of poor residents in townships through tourism will be extolled.

\section{References}

Alden, W. L. (2011). The law is to blame: The vulnerable status of common property rights in sub-Saharan Africa. Development and change, 42(3), 733 to 757.

Ashworth, G. J. (2004). Tourism and the heritage of atrocity: Management the heritage of South African apartheid for entertainment. In Singh, T (Ed.), New Horizons in Tourism: Strange Experiences and Stranger Practices. CABI, Wallingford.

Bonn, M. A., Joseph-Mathews, S. M., Dai, M., Hayes, S. \& Cave, J. (2007). Heritage/ cultural attraction and atmospherics: Creating the right environment for the heritage/ cultural sector. Journal of Travel Research, 45, 245-66.

Booyens, I. (2010). Rethinking township tourism. Towards responsible tourism development in South African townships. Development Southern Africa, 27(2), 273-287, DOI: 10.1080/03768351003740795.

Briedenhann, J. \& Ramchander, P. (2006). Township tourism: Blessing or blight? The case of Soweto in South Africa. In E. Smith \& M. Robinson (Eds.) Cultural tourism in a changing world: Politics, participation and re presentation (pp. 104-123). Clevedon: Chanel View.

Chachage, C. \& Mbunda, R. (2009). The state of the then NAFCO, NARCO and absentee landlords farms/ ranches in Tanzania (Unpublished Report) Dar es Salaam: Land Rights Research and Resources Institute (LARRI/ HAKIARDHI).

Diamonds, L. \& Plattner, M. F. (2010). Democratization in Africa. Progress and etreat. Baltimore, MD: The Johns Hopkins University Press.

Gasper, k., Mija, F., Mnisis, S., Mphusu, K. \& Pidduck, B. (2005).The Status of Tourism Development in Soweto: An Evaluative Study of Aspects of the Supply Side of Tourism. University of Johannesburg, Johannesburg.

Gauteng Tourism Authority (GTA). (2001). Soweto Tourism 2000- Developing Tourism in Soweto. Johannesburg: Gauteng Tourism Authority 
Honey, M. (2008). Ecotourism and sustainable development: Who owns paradise? (2nded.) Washington, DC: Island Press.

Jurgens, U., Donaldson, R., Rules, S. \& Bahr, J. (2013). Townships in South African cities: literature review and research perspectives. Habitat International, 39, 256-261

Nelson, F. (2011). Blessing or curse? The political economy of tourism development in Tanzania. Journal of Sustainable Tourism, 20(3), 359-375.

Nemasetoni, I. \& Rogerson, C. M. (2007). Township tourism in Africa: Emerging tour operators in Gauteng. In Rogerson, CM \& Visser, G (Eds), Urban Tourism in the Developing World: The South African Experience. Transaction, New Brunswick.

Ngxiza, S. (2012). Sustainable economic development in previously deprived localities: the case of Khayelitsha in Cape Town. Urban Forum, 23(2), 171- 187.

Page, S. J. (2003). Tourism management: Managing for change. London: Butterworth-Heinemann

Pirie, G. (2007). Urban tourism in Cape Town. In Rogerson, CM \&Visser, G (Eds), Urban Tourism in the Developing World: The South African Experiences. Transaction, New Brunswick.

Ramchander, P. (2007). Towards the responsible management of the socio-cultural impact of township tourism. In P.M. Burns \& M. Novelli (Eds.), Tourism and politics: global frameworks and local realities (pp. 149-165). Oxford: Elsvier.

Rogerson, C. M. (2004). Urban tourism and small tourism enterprise development in Johannesburg: A case of township tourism. Geo Journal, 60, 24458.

Rogerson, C. M. (2008). Shared growth in urban tourism: evidence from Soweto, South Africa. Urban Forum, 19(4), 391-401.

Rogerson, C. M. \& Visser, G. (2007). Urban tourism in developing world: The South African experience. New Brunswick: Transaction.

Rogerson, C. M. (2013). Urban tourism, economic regeneration and inclusion: evidence from South Africa. Local Economy, 38(2) 177-203.

Rolfes, M. (2010). Poverty tourism: theoretical reflections and empirical findings regarding an extraordinary form of tourism. Geo Journal, 75(5), 421- 442.

Rolfes, M., Steibrink, M. \& Uhl, C. (2009). Townships as attraction: an empirical study of township tourism in Cape Town. Report by the University of Potsdam, Germany.

Saayman, M., Rossouw, R. \& Krugel, W. (2012). The impact of tourism on poverty in South Africa. Development Southern Africa, 29(3), 422-452).

Scheyvens, R. (2002). Tourism for Development: Empowering Communities. Pearson Education, Harlow.

Sakolnakorn, T. P. N. (2013). Sustainable Tourism Development and Management in the Phuket province, Thailand. Asian Social Science, 9(7) 76-684.

Spenceley, A. (2008). Responsible Tourism: Critical Issues for Conservation and Development. Earthwatch, London.

UNWTO (United Nations World Tourism Organisation). (2006). Tourism and Least Developed Countries: A Sustainable Opportunity to Reduce Poverty. UNWTO, Madrid.

Van Staden, J. W. \& Marais, L. (2005). The tourism potential of Beaufort West: A study based on visitor demand. Development Southern Africa, 22(2) 233-56.

Visser, G. \& Kotze, N. (2006). The Free State tourism economy: Current dynamics, immediate challenges and future prospects. South African Geographical Journal, 88(1), 77- 102.

Visser, G. \& Rogerson, C. M. (2004). Researching the South African tourism and development nexus. Geo Journal, 60, 201-15.

Watanasawas, K. (2011). Authenticity under the management of nostalgic tourism: A case study of 100 years old Samchuk market, Suphanburi province. Journal of the Thai Khadi Research Institute, 8(2), 21-40. 